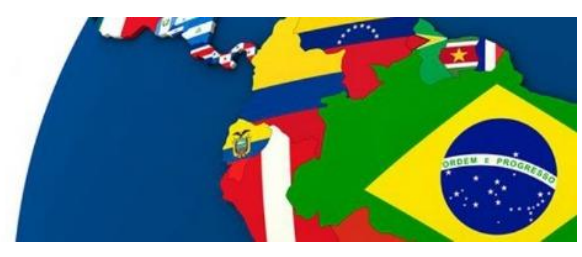

\title{
O PROCESSO DE CONSOLIDAÇÃO DA AUTONOMIA INDÍGENA DA NAÇÃO MONKOXÍ - TCO DE LOMERÍO NA BOLÍVIA ${ }^{1}$
}

Vívian Lara Cáceres Dan²

\begin{abstract}
RESUMO: Nesse artigo abordamos o contexto e mobilização da organização indígena Central Indígena das Comunidades Originárias de Lomerío (CICOL) que luta pela consolidação da autonomia e direitos indígenas na Bolívia, sua estrutura políticoadministrativa, e entender os elementos específicos dos enfrentamentos com o Estado boliviano para então avançar na discussão sobre o processo de descolonização e autonomias indígenas que vão além dos aspectos legais e institucionais. Utilizamos como fontes de análise: as atas das assembléias indígenas sobre o processo de autonomia, documentos das organizações indígenas Organização Indígena Chiquitana $(\mathrm{OICH})$ e CICOL, a fala das lideranças indígenas nas comunidades em que fizemos pesquisa de campo, a fala do advogado do Centro de Estudos Jurídicos e Investigação Social (CEJIS) e do assessor do Apoio ao Indígena Campesino do Oriente Boliviano (APCOB), estatuto dos indígenas Monkoxi de Lomerío, consulta a sites da Cedla, Clacso, Fundación Tierra, Observatório dos direitos dos povos indígenas e Ministério das Autonomias do Estado Boliviano, bem como autores que abordam a respeito da emergência das autonomias e regimes de autonomias em contexto latino americano. A pesquisa, além das fontes documentais e bibliográficas, também tem um cunho empírico com base em entrevistas das lideranças e anciãos que acompanham o processo de autonomia dessa etnia indígena na Bolívia, e portanto, a pesquisa é de viés qualitativo, contendo campo na forma de entrevistas e rodas de conversa. O problema principal aborda a questão: que tipo de autonomia indígena está sendo possível dentro do Estado Plurinacional boliviano?
\end{abstract}

Palavras-chave: autonomia; chiquitanos; direitos.

ABSTRACT: In this article we will discuss the context and mobilization of the Indigenous Central Indigenous Organization of the Indigenous Communities of Lomerío (CICOL), which fights for indigenous rights in Bolivia, its political-administrative structure, and understand the specific elements of the confrontations with the Bolivian State. discussion on the process of decolonization and indigenous autonomies that go beyond legal and institutional aspects. I use as sources of analysis: the minutes of the indigenous assemblies on the process of autonomy, documents of indigenous organizations Chiquitana Indigenous Organization $(\mathrm{OICH})$ and $\mathrm{CICOL}$, the speech of indigenous leaders in the communities where I did field research, the speech of the Center's lawyer of Legal Studies and Social Research (CEJIS) and the advisor of the Support to the Indigenous Peasant of the Bolivian Oriente (APCOB), status

\footnotetext{
${ }^{1}$ Artigo recebido em 30/04/2019 e aprovado em 17/07/2019

2 Doutora em Sociologia e Direito pela Universidade Federal Fluminense. Mestre em História Contemporânea pela Universidade Estadual do Oeste do Paraná. Possui licenciatura em História pela Universidade do Estado de Mato Grosso e graduação em Direito pela Universidade do Estado de Mato Grosso. Professora efetiva da Universidade do Estado de Mato Grosso, curso de Direito em Barra do Bugres. Atualmente é coordenadora do Curso de Direito de Barra do Bugres (UNEMAT). ORCID: orcid.org/0000-0001-9880-3028.
} 
of the indigenous Monkoxi of Lomerío, consult sites of Cedla, Clacso, Fundación Tierra, Observatory of the rights of indigenous peoples and Ministry of the Autonomies of the Bolivian State, as well as authors who discuss the emergence of autonomy and autonomy regimes in a Latin American context. The research, in addition to documentary and bibliographic sources, also has an empirical basis based on interviews of leaders and elders who accompany the process of autonomy of this indigenous ethnicity in Bolivia, and therefore, to research and qualitative perspective, field in the form of interviews and conversation. Or does the main problem address the question of what kind of indigenous autonomy is being pursued within the Bolivian Plurinational State?

Keywords: autonomy; chiquitanos; rights.

\section{Introdução}

Nesse artigo iremos abordar o contexto e mobilização da organização indígena Central Indígena das Comunidades Originárias de Lomerío (CICOL) que luta pela autonomia e direitos indígenas na Bolívia, sua estrutura político-administrativa, e entender os elementos específicos dos enfrentamentos com o Estado boliviano para então avançar na discussão sobre o processo de descolonização e autonomias indígenas que vão além dos aspectos legais e institucionais. Utilizamos como fontes de análise: as atas das assembleias indígenas sobre o processo de autonomia, documentos das organizações indígenas Organização Indígena Chiquitana $(\mathrm{OICH})$ e CICOL, a fala das lideranças indígenas nas comunidades em que fiz pesquisa de campo, a fala do advogado do Centro de Estudos Jurídicos e Investigação Social (CEJIS) e do assessor do Apoio ao Indígena Campesino do Oriente Boliviano (APCOB), estatuto dos indígenas Monkoxi de Lomerío, consulta a sites da Cedla, Clacso, Fundación Tierra, Observatório dos direitos dos povos indígenas e Ministério das Autonomias do Estado Boliviano, bem como autores que abordam a respeito da emergência das autonomias e regimes de autonomias em contexto latino americano. A pesquisa, além das fontes documentais e bibliográficas, também tem um cunho empírico com base em entrevistas das lideranças e anciãos que acompanham o processo de autonomia dessa etnia indígena na Bolívia.

Perceberemos vários olhares sobre o processo de descolonização e construção da autonomia, pensados a partir de sua estrutura organizacional, leis específicas e da mobilização desses atores sociais que podem estar acionando uma autonomia jurídica e cultural que em alguma medida provoca uma redefinição do Estado, um impacto em seu funcionamento, estrutura política e na forma de fazer política a partir mesmo dessa reação de dentro do Estado. 


\section{O caso de autonomia do Território Comunitário Originário (TCO) de Lomerío}

Lomerío é uma Terra Comunitária Originária (TCO) chiquitana em processo de se tornar um Território Indígena Originária Comunitária (TIOC de Lomerío para o Estado), nação indígena chiquitana de Monkóxi, que se encontra no departamento de Santa Cruz, província de Ñuflo de Chávez, com vinte e oito (28) comunidades, distribuídas em quatro (4) regiões ou cantões: San Antônio com 9 comunidades, Santa Rosa del Palmar com 6 comunidades, El Puquio com 6 comunidades e San Lorenzo com 7 comunidades (FUNDACIÓN TIERRA, 2010).

A região faz parte da grande chiquitania e o censo de 2012 indica uma população perto dos 6.500 habitantes. Um dos problemas do baixo crescimento populacional é o fato de muitos jovens migrarem para os grandes centros urbanos em busca de trabalho ou mesmo estudos (Concepción, San Javier e Santa Cruz) e não voltarem para suas comunidades de origem (FUNDACIÓN TIERRA, 2010).

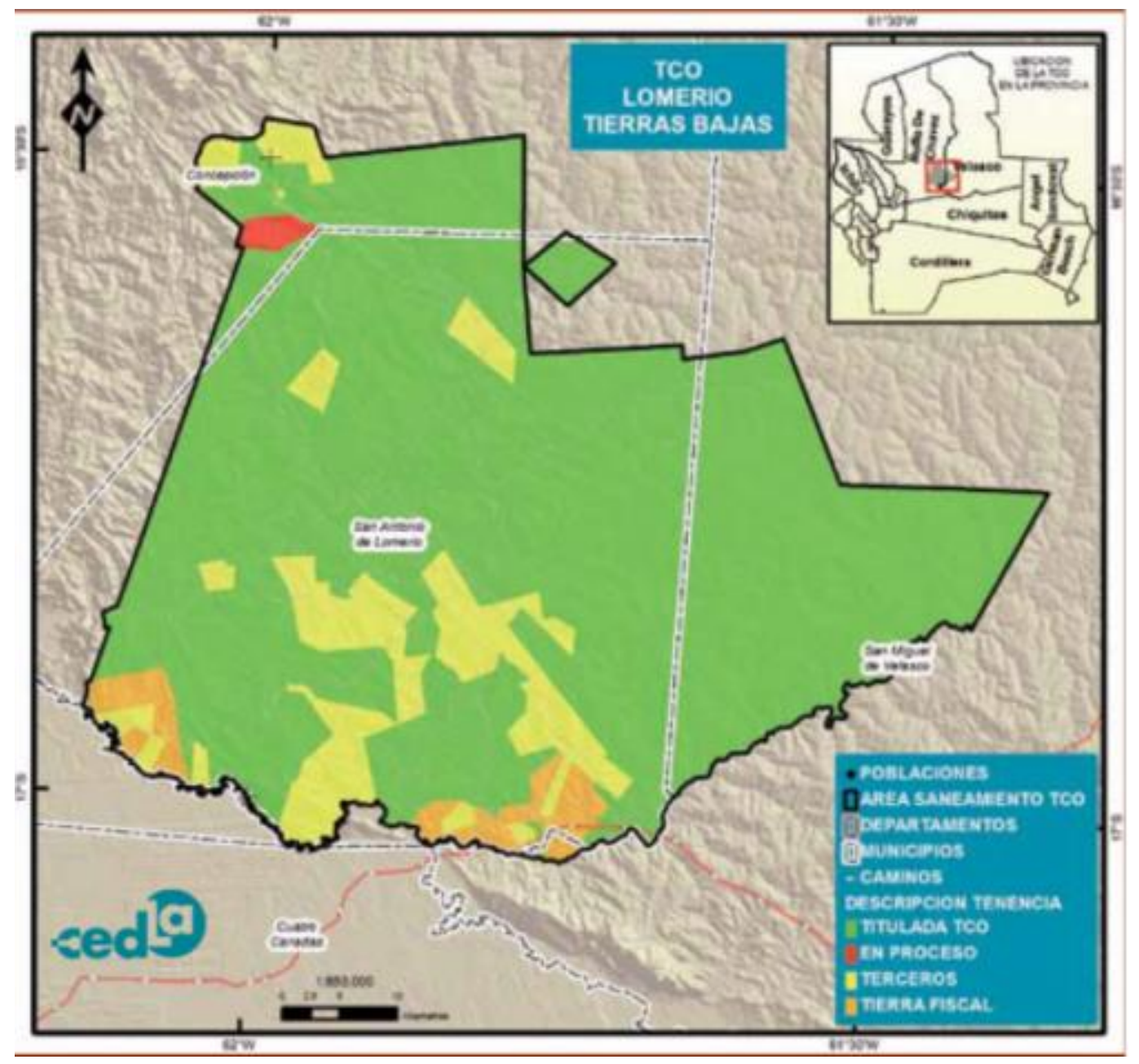

Mapa 1: TCO Lomerío

Fonte: CEDLA (2010). 
No ano de 1982, a nação indígena Monkoxi fundou a Central Indígena das Comunidades Originárias de Lomerío (CICOL), que se destacou como uma importante organização política da TCO para articulação dos direitos dentro do movimento indígena. Também fundaram a atual Confederação dos Povos Indígenas da Bolívia que era chamada de Central Indígena do Oriente Boliviano (CIDOB). Mobilizaram-se em torno das Marchas Indígenas que iniciaram nos anos 1990, entre elas, a Marcha pelo Território e Dignidade em 1996, Marcha pela Terra, Território e Recursos naturais no ano de 2000 e a Marcha pela Assembleia Constituinte que ocorreu em 2002 (ESTATUTO DE LOMERIO, 2013).

Em 1996, os chiquitanos iniciaram a demanda por seu território ancestral e a CICOL conseguiu a titulação de 259.188 hectares que conforma a Terra Comunitária de Origem de Lomerío onde a capital é El Puquio. A TCO ultrapassa os limites do município, o município é parte do órgão do governo (alcadía) e existem algumas diferenças entre a TCO e o município já que neste existem algumas propriedades particulares que não fazem parte do território indígena, sua gestão é pautada no Plano de Desenvolvimento Municipal e a TCO tem seu próprio Plano de Gestão Territorial indígena (GTI) ${ }^{3}$ (ARAOZ \& FERANDÉZ, 2010, p. 56).

A estrutura organizacional da CICOL tem dois níveis: uma modalidade que acontece nas comunidades e a outra modalidade, na TCO. Cada comunidade foi uma Organização Territorial de Base (OTB) e tinha um diretor da OTB, um "cabildo" ou um "alcalde comunal", mas hoje tem uma assembleia comunal e as autoridades comunais são delegados, ou autoridades comunais. As vinte e oito (28) comunidades se organizam em torno da CICOL. As decisões são tomadas em assembleias a nível de TCO, a partir da deliberação de todos participantes (delegados) e essa representação é exercida no diretório da CICOL (ESTATUTO ORGÂNICO DA CICOL, 2008).

Assim, a instância máxima na CICOL é a assembleia geral das comunidades e é a CICOL que estabelece as linhas de ação como parte do Plano de Gestão Territorial (PGT) da TCO, entre as quais, o controle territorial e o fortalecimento das organizações integradas também ao Plano de Desenvolvimento Municipal (PDM) e que por um tempo foi possível manter diálogo entre a TCO e o município.

\footnotetext{
${ }^{3}$ Os chiquitanos têm pensado na Gestão Territorial Indígena como um processo de recuperação e ocupação do território buscando o desenvolvimento tanto dos povos enquanto cultura, organização própria como de desenvolvimento sem alterar ou explorar a natureza de forma depredatória. Esse conceito faz parte da própria definição de "autogobierno", o que gera tomada de decisões conjuntas sobre a organização, o território,a população, planificação, administração e uso dos recursos naturais de forma sustentável definido dentro dos marcos culturais específicos.
} 
Nas referidas comunidades, os delegados que as representam as comunidades nessas assembleias, são os responsáveis por cumprir e fazer cumprir as decisões ali tomadas, os quais estão respaldados por esta base representativa (ESTATUTO DA CICOL, 2008). Nos dois tipos, portanto, existe um sistema de representação e de decisão.

Quando abordamos a categoria autonomia, esta remete à possibilidade do autogobierno, ou seja, trata-se do direito das comunidades poderem gerir seus próprios recursos, governarem seu próprio território, com suas próprias normas devendo, assim, verem respeitados a sua cultura, suas formas de organização incluindo ai, as normas políticas e jurídicas próprias dessas comunidades. A categoria autonomia indígena estaria ligada ao processo de descolonização e ao paradigma do Estado plurinacional implementado pelo governo boliviano a partir da nova Constituição de 2009.

Segundo o advogado do Centro de Estudos Jurídicos e Investigação social (CEJIS) em entrevista:

\begin{abstract}
No ano de 2008, portanto, antes da aprovação da Constituição Política da Bolívia, a Assembleia Geral das comunidades declarou a TCO de Lomerío como o primeiro território indígena autônomo da Bolívia, ou seja, a primeira nação indígena autônoma, a nível nacional. Construíram, em 2009, seu estatuto de forma participativa por um Conselho Consultivo da autonomia e elaboraram seu estatuto de autonomia antes mesmo da lei de autonomias de 2010, momento em que já tinham um órgão deliberativo (VARGAS, MIGUEL, 2015) ${ }^{4}$.
\end{abstract}

Em 2013, segundo Vargas e García, as comunidades representadas nas assembleias e conselhos consultivos adequaram seu estatuto ao que o artigo 62 da lei de autonomias estabelecia e optaram pelo processo via territorial e não municipal para consolidarem sua autonomia. Entre as motivações, apontadas por Vargas e García (ex alcalde de Lomerío) em entrevista, está o fato de que a jurisdição territorial da TCO é maior que a do município e se escolhessem a via municipal iriam perder território (VARGAS, Miguel; GARCÍA, Ignácio, 2016).

Outra possível motivação apontada por Vargas para escolherem a via territorial de autonomia é o fato da Lei Marco de Autonomias e Descentralização (LMAD, 2010) e o estatuto de Lomerío (2013) representarem muito mais que uma simples regionalização ou descentralização de estrutura político administrativa conferindo a esses territórios um novo regime de governo. Ou seja, a partir do reconhecimento constitucional da autonomia territorial que precisa necessariamente criar jurisdições étnicas indígenas, ou multiétnica

\footnotetext{
${ }^{4}$ En el año 2008, por lo tanto, antes de la adopción de la Constitución de Bolivia, la Asamblea General de las comunidades declaró Lomerío TCO como el primer territorio indígena autonomico de Bolivia, es decir, la primera nación autonomica a nivel nacional. Construido en 2009, su estado de forma participativa por un Consejo Asesor de la autonomía y desarrolla su autonomía ante la ley 2010 la autonomía, a la que ya tenía un órgano de deliberación.
} 
reconhecida pelo Estado como parte da ordem política e administrativa estatal e em seu interior, devendo estabelecer autoridades próprias (entidades territoriais indígenas originárias campesinas) para os indígenas exercerem efetivamente seu direito à autodeterminação. Entregaram o estatuto para análise no Tribunal Constitucional Plurinacional, ainda em 2013 e para o controle de constitucionalidade. O processo de consolidação de autonomia via Estado requer que o Estatuto seja encaminhado para o Tribunal para análise e controle de constitucionalidade. A Constituição, em seu capítulo VI, dispõe sobre o tema Tribunal Constitucional Plurinacional nos arts. 196 a 204. E o art. 197, I, estabelece que esse Tribunal deve ser integrado por magistrados e utilizar os critérios de plurinacionalidade com representação, tanto do sistema ordinário quanto do sistema indígena originário campesino (CPE, 2009). Portanto, a Constituição Política do Estado Plurinacional estabelece um sistema judicial em que reconhece o pluralismo jurídico mediante a incorporação e integração da Justiça Originária Campesina à administração da justiça vigente. Lomerío recebeu seu certificado de ancestralidade, mas a análise de seu estatuto pelo TCP se encontra paralisado.

Segundo informações do Observatório dos Direitos dos Povos Indígenas (ODPIB), notícia de 16 de dezembro de 2015, conseguiram depois de muita pressão, o certificado de viabilidade governativa e o de base populacional. Esses certificados fazem parte das etapas para consolidarem as autonomias indígenas. São analisados pelo Ministério das Autonomias onde $\mathrm{o}$ de viabilidade governativa diz respeito a estrutura organizacional de base administrativa, se está ou não coerente, e o de base populacional é referente a quantia de pessoas que participaram das discussões e decisões de base comunitária para endosso das referidas autonomias. Sem esses documentos, a autonomia não segue para as próximas etapas. A XXXIII Assembleia Ordinária de Comunidades de Lomerío ocorreu em 15 de dezembro deste ano e o vice-ministro de autonomias indígenas originárias campesinas esteve presente para entregar esse certificado. Somente com esse documento, o Tribunal pode iniciar a análise e o controle de constitucionalidade de seu estatuto que já se encontra no TCP desde 2013. Mas são os únicos, outros sete (7) processos também estão paralisados nesse mesmo requisito legal.

\subsection{O processo de consolidação da autonomia a partir das impressões das lideranças indígenas de Lomerío e da Cejis}

Miguel Vargas, que atua junto a CICOL em entrevista, esclarece que inicialmente a autonomia indígena foi percebida como uma nova institucionalização do exercício de poder 
político para povos historicamente marginalizados através da qual tentariam resolver os problemas de exclusão, pobreza rural e desigualdade social, uma vez que promoveriam diversos objetivos com a descentralização política, a melhoria dos serviços sociais básicos, a participação local e o desenvolvimento econômico.

Vargas também enfatiza que com a aprovação da LMAD (2010) passaram a ver o processo de outra forma:

O processo de autonomia visto apenas como um cumprimento de requisitos legais é muito limitado, e deveria estar considerando o contexto político, social, cultural, econômico de cada um dos territórios indígenas, em função da consolidação desse "autogobierno" (VARGAS, 2015).

\section{E complementa:}

É muito pouco provável que esses processos de autonomias indígenas agirão e trarão o impacto necessário para consolidarem-se como verdadeiros instrumentos de emancipação enquanto gestão, uma vez que os municípios irão perder para as TIOC,s poder econômico e político, nos casos de Lomerío e Monte Verde, já que perderão cerca de 2.000 habitantes enquanto ocupação territorial da jurisdição municipal, assim também parte das florestas que são importantes meios para capitanear recursos para o governo municipal com impostos de extração ou mesmo das atividades nessa jurisdição municipal conduzidas. Então o tema de autonomia é mais complexo do que se pensa ${ }^{6}$ (VARGAS, 2015).

Ainda segundo ele:

Como um certificado, um documento administrativo pode significar o poder de autorizar o funcionamento de justiças e sistemas de organizações indígenas, dando legitimidade a um direito já reconhecido pela Constituição e por organismos internacionais?...não deveria ser assim porque o mesmo já foi reconhecido antes pelos nativos e também por tratados internacionais. $\mathrm{O}$ regulamento não deveria inviabilizar...seria um absurdo não deixarem os indígenas governar seu território que tanto lutaram para conseguir reestabelecer esse direito ${ }^{7}$ (VARGAS, 2015).

\footnotetext{
${ }^{5}$ El processo de autonomia visa solamente como un cumplimiento de requisitos legales es muy limitado, y deberia estar considerando el contexto politico, social, cultural, econômico de cada un de los territórios indigenas, en función de la consolidación de este autogobierno.

${ }^{6}$ Es muy poco probable que ese procesos de autonomias indigenas agiran y tratarán el impacto necesário para se consolidan como verdadeiros instrumentos de emancipaciones encuanto gestión, una vez que los municípios irán perder para las TIOC,s poder econômico y politico, en los casos de Lomerío y Monte Verde, ya que perderán acerca de 2.000 habitantes encuanto ocupación territorial de la jurisdición municipal, asi también parte de las florestas que son importantes medios para capitanear recursos para el gobierno municipal con impostos de extración o mismo de las atividades en esa jurisdición municipal conduzidas. Entonces el tema de autonomia es más complexo de que se pensa.

${ }^{7}$ Como un certificado, un documento administrativo puede significar el poder de autorizar el funcionamento de justicias y sistemas de organizaciones indigenas, dando legimitad a un derecho ya reconocido por la Constituición y por organismos internacionales?...no deberia ser asi porque lo mismo ya fue reconocido antes por los nativos y también por tratados internacionales. El regulamento no deberia inviabilizar...seria un absurdo no dejaren los indigenas gobernar su território que tanto pelearan para lograr reestablecer ese derecho.
} 
No atual momento, esses procedimentos estão travando o processo e, ocorre uma homogeneização da forma como se pensa o cumprimento desses requisitos que, mesmo se tratando de diferentes nações e cada uma delas tendo uma forma específica de se definir em termos de democracia comunitária, suas decisões, normas e organizações sociais e políticas, essas especificidades não estão sendo consideradas.

Outros problemas foram apontados por Vargas quando abordou o processo de consolidação dessas autonomias dentre elas, e a longo prazo está a questão da governança interna que passa por questões políticas e também sobre o uso dos recursos naturais, tais como forma de manejo, aproveitamento florestal, e em que condições isso vai ocorrer essa exploração dos recursos naturais do território. Outro fator importante é sobre a estruturação política das comunidades, já que os jovens estão indo embora para as cidades em busca de trabalho e estudos e não estão voltando para as comunidades (VARGAS, 2015).

Segundo Ignácio García, ex alcalde de Lomerío, entrevistado em dezembro de 2016:

O Estado prioriza a via municipal e não territorial de autonomia e embora Lomerío tenha sido um projeto piloto em relação à autonomia ainda não fomos reconhecidos legalmente, parece que estamos sendo punidos por não escolher a via municipal, mas queremos a via territorial onde a autonomia sairá pela TCO e não pelo município, consideramos o nosso território como a base do governo próprio e autônomo, essa é nossa forma genuína de governança ${ }^{8}$ (GARCÍA, 2016).

Ignácio García salienta ainda que:

Os povos indígenas sempre cuidaram de seu território e recursos naturais por isso nos corresponde o direito de administrá-lo um dia. No ano de 2014, ocorreram 31 assembleias das quais 22 das 28 comunidades de Lomerío participaram e, de maneira oral, expressaram o apoio ao processo de autonomia' (GARCÍA, Ignácio, 2016).

Interessante também é a fala do 1 "gran cacique" da CICOL, o sr. Anacleto Peña que em entrevista, em dezembro de 2015, ressalta:

As comunidades indígenas como povo pré-colonial são autônomos, vivemos a autonomia nas comunidades. Temos nossas normas e procedimentos próprios transmitidos oralmente e escrito de geração a geração. Queremos sim o reconhecimento do Estado, que aqui vamos chamar de autonomia de base territorial para Lomerío, esse é documento do Estado que nos reconhece apenas legalmente. Nós sempre exercermos independente do

\footnotetext{
${ }^{8}$ El Estado prioriza la vía municipal y no territorial de autonomia y aunque Lomerío tenía sido un proyecto piloto en relación a la autonomia todavia no fomos reconocidos legalmente, parece que estamos sendo castigado por no elegir la vía municipal, pero queremos la vía territorial donde la autonomia salirá por la TCO y no por el município, consideramos el nuestro território como la base del gobierno y autonómo, esa es nuestra forma genuína de gobiernancia.

${ }^{9}$ Los pueblos indigenas siempre cuidarán de su território y recursos naturales por eso nos corresponde el derecho de gestionarlo un día. Em el año de 2014, ocurrerán 31 asamblea de las cuales 22 de las 28 comunidades de Lomerío participaran y, de manera oral, expresaran el apoio al proceso de autonomia.
} 
reconhecimento do Estado. Queremos por ser um direito nosso, o direito à autodeterminação, de governo próprio com base territorial $^{10}$ (PEÑA, Anacleto, 2015).

Para eles, trata-se portanto, de consolidação de autonomia e não construção de uma, ou seja, é uma autonomia legitimada sócioculturalmente por ser algo preexistente. E nesse sentido, o processo de autonomias indígenas não são apenas um processo jurídico mas social e político e vem fortalecendo essas capacidades organizativas e de mobilização, na medida em que esses grupos lutam por esse reconhecimento legal, se organizam, pressionam o governo para além de cumprir os requisitos legais.

Por isso, a atuação dessa nação indígena para ver a consolidação da sua autonomia está demonstrando ser um processo legítimo, e levando à mobilização dessas comunidades que, de fato, possibilita um empoderamento dos mesmos na medida em que precisam se articular, fazer as assembleias, estudar as leis, adaptar seus estatutos, informar e votar as decisões nas comunidades, aprofundando a participação popular e pressionando o Ministério de Autonomia a dar respostas, a se reunir com eles e ouvi-los nesse processo.

A autonomia territorial defendida como a escolha de Lomerío tem como critério central o exercício dos direitos coletivos de autodeterminação e controle das suas instituições políticas baseados na visão das suas comunidades indígenas. Os líderes indígenas estão enfatizando que não se trata de uma "construção" ou execução de etapa para "ascenderem" e sim da "consolidação" da autonomia que já existe.

González destacou que, embora essa produção de regulamentos ocorra no interior do Estado, uma característica dessas autonomias territoriais é que elas circulam em torno da tensão entre poderes, visões e jurisdições compartilhadas com o Estado (GONZÁLEZ, 2008, p. 78).

Por isso, o meu olhar também se dedica a esses pontos de tensão inerentes ao processo de consolidação da autonomia em relação ao Estado, que em outro item será melhor detalhado para que possam assim ser interpretados como possíveis elementos desse empoderamento dos protagonistas indígenas.

\footnotetext{
10 Las comunidades indigenas como Pueblo precolonial son autónomos, vivimos la autonomia en las comunidades. Tenemos nuestras reglas y procedimentos próprios transmitidos oralmente y escrito de generación a generación. Queremos sí el reconocimento do Estado, que aquí vamos llamar de autonomia de base territorial para Lomerío, ese es documento do Estado que nos reconoce solamente legalmente. Nosotros siempre ejercermos independente de lo recocimento do Estado. Queremos por ser un derecho a la autodeterminación, de gobierno próprio con base territorial.
} 


\subsection{Sistema de organização política administrativa chiquitana: CICOL - Lomerío}

A forma de organização do povo chiquitano, que no passado foi formado por famílias, clãs e caciques, se transformou juntamente com as mudanças sociopolíticas do país. Durante as missões (1692-1767), o cabildo constituiu-se como um sistema que articulava os costumes indígenas à estrutura das missões (PUHL, 2011, p. 78).

A máxima autoridade do cabildo era o cacique geral, apoiado por vários caciques líderes de cada grupo dos diferentes indígenas nas missões. Os caciques eram assistidos por um corregedor, que era espanhol. Também existia uma forma de organização das atividades produtivas e artesanais, seguido dos trabalhos de carpintaria, ferraria, tecelagem, música, agricultura, criação de animais etc. E todos estavam sob a responsabilidade dos fiscais dos trabalho, da fazenda e dos capitães das oficinas de artesanato (PUHL, 2011, p.81).

No projeto de afirmação nacionalista na Bolívia, mineradora e latifundiária (como por exemplo, o Movimento Nacionalista Revolucionário - MNR - partido de orientação nacionalista e pequeno burguesa) que implantou um novo governo em 1952, quanto o Estado pretendiam integrar os indígenas à sociedade nacional. A primeira lei de Reforma Agrária da Bolívia em 1953 por meio do Decreto Lei 3464/1953 deixou evidente que o acesso à terra só era possível com a condição de serem identificados como grupos de camponeses organizados em sindicatos.

No estudo sobre o impacto dessa política em relação aos grupos da etnia chiquitana, Puhl observou que como estratégia do Estado para garantir a assimilação das populações chiquitanas, foi possível a entrega de títulos de lotes individuais muitas vezes em terras comunitárias $^{11}$. Os títulos de terras eram emitidos sobre lotes familiares ou a uma pessoa da comunidade e não em nome de uma entidade coletiva ou pessoa jurídica, pois, entendiam tratar-se de comunidades camponesas (PUHL, 2011, p. 81).

Incentivou-se a modernização agropecuária, a renomeação das comunidades indígenas rurais como campesinas, a reforma educativa (escolas rurais e públicas com professores pagos pelo Estado a partir da década de 1950 ensinando a língua nacional, o espanhol e no caso dos chiquitanos, o desestímulo de falarem seu dialeto "bésiro"), ou seja estimulou-se a des-indianização com políticas de educação escolar e reforma agrária, direcionando o processo de introdução à sociedade nacional (PUHL, 2011, p.88).

\footnotetext{
${ }^{11}$ No estudo de Puhl (2011) ele faz menção das Comunidades Supunemas e Pailitas (comunidades chiquitanas de Santa Ana) em que o primeiro título das terras foi emitido em nome somente de um dos membros da comunidade e que hoje estão em processo de revisão e saneamento.
} 
Aos sindicatos camponeses foi atribuída a função de legítimos representantes das comunidades para demandar a restituição de terras e os representantes deveriam ser membros da comunidade e residentes do lugar. Esse objetivo foi articulado pelo Estado, Igreja Católica, sindicatos e ONGs e outros organismos internacionais. De acordo com Puhl, ao estimularem a formação de lideranças locais em termos sindicais ou cooperativos, tratava-se de comunidades sem esse tipo de experiência, pois na década de 1950 e 1960 essa situação de composição de autoridades locais da comunidade para organizar esses sindicatos ou cooperativa era muito precária (PUHL, 2011, p.92).

Ainda segundo o mesmo autor, a legislação era restritiva além de ser uma medida que tentou despolitizar a atuação das comunidades indígenas, pois a lei reconheceu os sindicatos e não as comunidades como formas de organizações legítimas para executar a reforma agrária, excluindo as formas indígenas de organização e proibindo as comunidades camponesas de se associarem às estruturas mais amplas do que a organização local limitando a atuação dessas lideranças ao aspectos político local (PUHL, 2011, p. 93).

Puhl afirma que os cargos de Alcalde político, Cabildo campesino, cacique, grupo de anciãos se mostraram como organizações típicas da década de 1940 até 1994 nas comunidades chiquitanas. Na década de 1980, a partir de sua pesquisa em fontes orais e escritas, constatou-se o aparecimento das Juntas escolares, clube de mães, grupos de trabalho, Associação MINGA (Cooperativa de produtores agrícolas membros das comunidades chiquitanas em San Ignácio), Cabildos indígenas em lugar do Cabildo campesino, Centrais Indígenas Regionais ou municipais, o que confluiu para a criação da Organização Indígena Chiquitana (OICH) em 1988 (PUHL, 2011, p. 88).

Já na década de 1990, segundo o mesmo autor, originaram-se as Organizações Territoriais de Base (OTBs) que acabaram se tornando um "poder paralelo" e concorrente com o dos cabildos dentro do que era reconhecido como "legítima organização tradicional chiquitana" (PUHL, 2011, p.79). Os chiquitanos, aos poucos, abandonaram essa identidade camponesa que the foi imposta pelos governos nacionalistas e movimentos sindicais camponeses e retomaram a identidade indígena.

Justo Seoane, atual 1 "gran cacique general” da Organização Indígena Chiquitana (OICH) em entrevista em janeiro de 2015, explica sobre a composição dos poderes chiquitanos e, relata especificadamente sobre Lomerío que devido à Reforma Agrária (a partir de 1953), devido ao movimento sindical gerado em todo o país, e à formação da Organização Indígena do Oriente Boliviano em 1982, dezessete (17) comunidades indígenas estabelecidas em uma zona do departamento de Santa Cruz se organizaram em torno da Central 
Intercomunal Campesina do Oriente Lomerío (CICOL) com uma base estrutural do tipo sindical e mantiveram a representação das comunidades (SEOANE, Justo, 2015).

Nessa configuração existiam "alcaldes comunales" ou políticos vinculados aos partidos políticos da província de Santa Cruz e finalmente, com a Lei de Participação Popular de 1992, as comunidades de Lomerío passaram a formar uma nova estrutura de organização comunitária, as OTB,s ou organizações territoriais de base, similares à organizações sindicais camponesas. Nesse sentido, nos anos 2000, cada comunidade chegava a ter duas ou três autoridades paralelas de funções similares e embora tentassem ser complementares criava- se grande confusão na população e debilitava a base representativa e organizacional dos chiquitanos de Lomerío.

Até os anos 1980, segundo Seoane da $\mathrm{OICH}$, na região da chiquitania, o termo “indígena" era utilizado pejorativamente aos se referir aos grupos indígenas, e também aos que se organizaram em torno da CICOL. Mas, com a emergência do movimento indígena dentro e fora da Bolívia, e com a declaração da Convenção n. 169 da OIT, as implicações de ser indígena passaram por uma mudança, principalmente porque neste novo contexto, tinham direito ao reconhecimento de sua cultura e de seu território até então negados (SEOANE, Justo, 2015)

Foi um processo gradual de retomada das comunidades rurais como indígenas chiquitanas que ainda está em construção a partir da autodeterminação dessa população destruindo assim a autoimagem de mestiços, camponeses, cambas, seringueiros, e que a sociedade e o próprio Estado, presidido por um bloco camponês, indígena e popular posteriormente também veio a reconhecer enquanto povos originários.

Em 1997, questionaram sua estrutura camponesa sindical e a denominação de Central Intercomunal Campesina do Oriente Lomerío modificando a nomenclatura para Central Indígena de Comunidades Originária de Lomerío e iniciaram um processo de fortalecimento da identidade indígena dentro do seu território. Outras onze (11) comunidades também passaram a compor a CICOL totalizando vinte e oito (28) comunidades em torno dessa organização.

Percebemos com a análise e explicações sobre o quadro abaixo, que eles estabeleceram uma nova estrutura aprovada no ano de 2008, que constituiu uma construção complementar entre a forma tradicional de organização (alcaldes), somado a influência da organização sindical (OTB) e à articulação de novas instâncias técnico-operacionais criadas com o incentivo da CICOL e das ONG,s que atuam em Lomerío. 
Assim, nessa nova estrutura todas as mulheres e homens, distribuídos nas vinte e oito (28) comunidades formam a base da organização e conformam a autoridade máxima da CICOL que é a assembléia. A assembleia ${ }^{12}$ delibera e decide através de um sistema de representação constituído por cento e sessenta e oito (168) delegados comunais (seis por comunidade). A instância encarregada de executar e fazer cumprir as decisões da Assembléia é o diretório, constituído por nove caciques que exercem representação na CICOL.

O quadro a seguir demonstra a atual organização político administrativa da CICOL desde 2008.

\section{Quadro 4: Estrutura organizacional da CICOL - Lomerío}

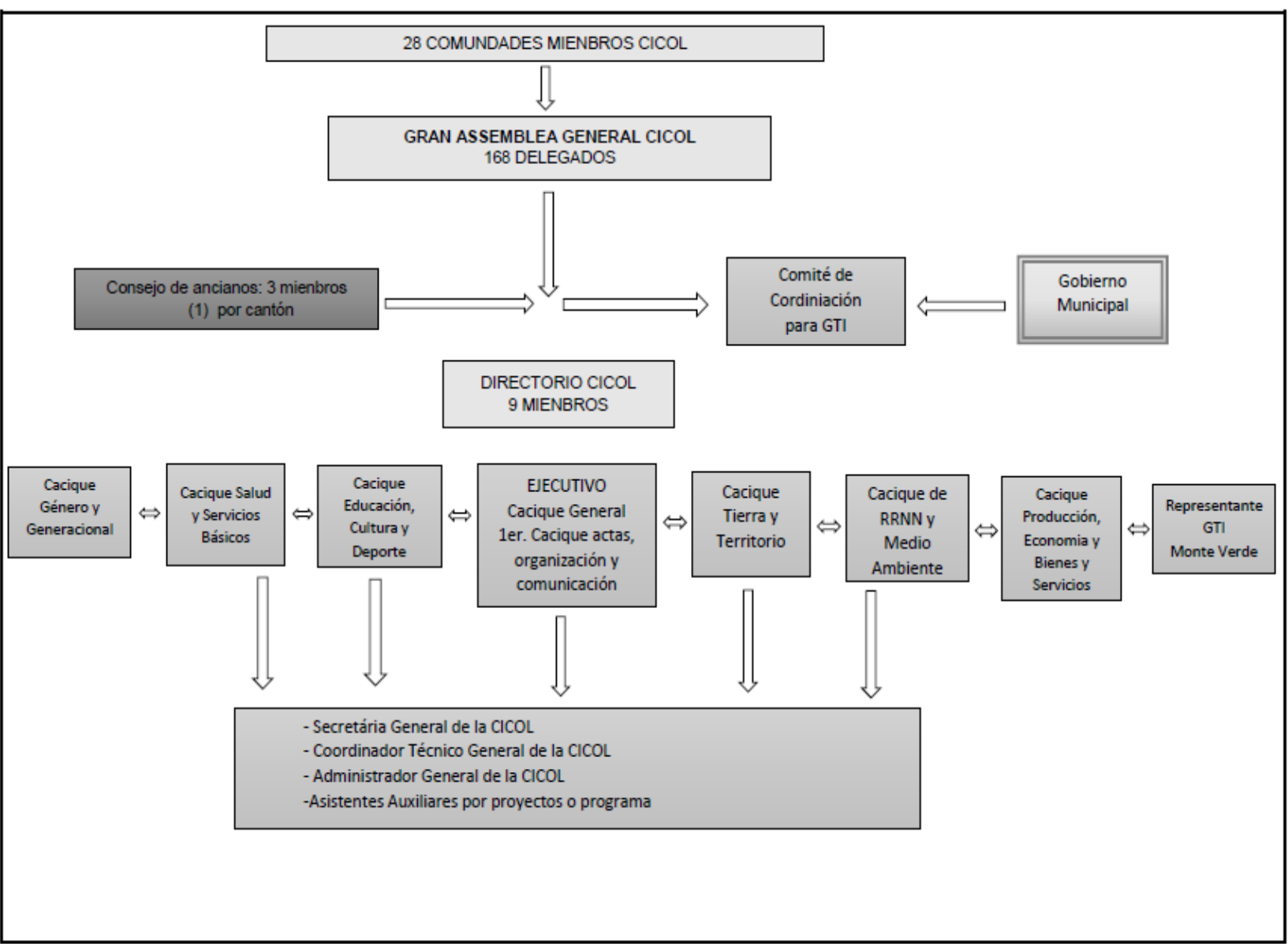

Fuente: CIDOB-GTI (2007). Nueva estrutura organizativa aprobada por la CICOL el anõ 2008 .

Conforme Peña explicou em entrevista, o diretório prevê o funcionamento de uma equipe técnica para facilitar o cumprimento do mandato desses membros com a perspectiva de otimizar a gestão dos assuntos e recursos da organização através de uma adequada

${ }^{12}$ Mesmo recebendo outra denominação e sendo um órgão coletivo tem-se que é muito parecido com o Poder Executivo e Legislativo nos moldes do Estado Moderno. Ficando o Poder Judiciário conformado na estrutura de Conselho de Anciãos e cabildos indígenas. 
administração e assessoramento técnico. Por isso, na estrutura político-organizacional foram incorporadas uma secretária, um assistente técnico auxiliar para projetos e um administrador geral da CICOL. No mesmo nível também está uma equipe técnica da Gestão Territorial Indígena (GTI) com membros que representam inclusive o governo municipal e que apoiam e assessoram o diretório facilitando as ações planificadas para o povo chiquitano tanto dentro quanto fora da TCO (PEÑA, Anacleto, 2015).

Como podemos perceber no quadro acima, entre a assembleia e o diretório existem três (3) instâncias intermediárias: o Conselho dos Anciãos, o Comitê de Gestão Territorial indígena (GTI) e o governo municipal (ESTATUTO ORGÂNICO DA CICOL, 2008). Nessa estrutura organizacional própria são mantidos o que entendemos como Poderes Executivo, Legislativo e Judiciário.

Peña explica que:

Essas instâncias intermediárias mostram a revalorização cultural do sistema organizacional antigo, sistema no qual incorpora a sabedoria dos anciãos que são uma espécie de guias na tomada de decisão. Por outro lado, existe um esforço de criar instâncias que possibilitem a gestão do território e dos recursos com o fortalecimento dessa capacidade técnica ${ }^{13}$ (PEÑA, 2015).

Assim, Peña salientou que o Conselho de Anciãos constitui uma instância que ajuda na administração da justiça e aplicação da sanção/pena. Trata-se de um conselho que resolve problemas que não podem ser solucionados no diretório da CICOL porque são conselheiros morais, que baseiam suas decisões em suas experiências e sabedoria mas também fiscalizam e aprovam ações do Diretório quando, por exemplo, aprovam previamente à assembléia, os informes do Executivo e as decisões dos anciões devem estar de acordo com a da Assembléia (PEÑA, Anacleto, 2015).

Já o Comitê de Gestão Territorial está composto por um grupo de cinco (5) membros, eleitos pelo Diretório da CICOL, pelo governo municipal e pelo Comitê de vigilância do município cujo papel é o de articular o planejamento e ações da CICOL com o governo municipal (ESTATUTO ORGÂNICO DA CICOL, 2008). Então não se trata apenas de um governo municipal que atua ou interfere na TCO mas, a CICOL também interferiu e atuou nos planejamentos e na gestão municipal.

Segundo Peña, a territorialidade dentro do sistema organizacional é importante para o critério de representatividade porque tanto as comunidades quanto os "cantões" que elas

\footnotetext{
13 Esas instancias intermediarias monstran la revalorización cultural de lo sistema organizacional antiguo, sistema por lo cual incorpora la sabiduría de los anciones que son una espécie de guías en la tomada de decisión. Por outro lado, existe un esfuerzo de criar instancias que posibiliten la gestión del território y de los recursos con el fortalecimento de esta capacidad técnica.
} 
fazem parte (sendo quatro cantões) são instâncias através das quais eles podem assumir representação. A eleição "cantonal" ocorre para o conselho de anciões e para a distribuição dos cento e sessenta e oito (168) delegados, seis (6) por comunidades dentro dos cantões ou regiões (PEÑA, 2015).

Conforme quadro acima, já exposto sobre o sistema organizacional da CICOL, existem nove (9) caciques no total, e o cacique geral e o 1 "gran cacique" são os representantes responsáveis pelos procedimentos das assembleias, ou seja, pela função de administradores (Executivo), de organização e comunicação, atendimento dos temas ou áreas onde estão responsáveis os outros caciques, como educação, território, produção, saúde, etc.

Alguns temas ou áreas foram incluídos como gênero e cultura devido à necessidade de adaptarem-se às mudanças externas e internas às comunidades. Há também um representante da TCO Monte Verde que tem a mesma função dos outros caciques, sendo também eleito por assembleia e tendo a função estratégica de articular ações que realizam junto ao comitê, à organização de Monte Verde e com a CICOL.

O funcionamento dessa estrutura da CICOL tem como base fundamental a Assembleia Geral Ordinária, momento em que se toma todo tipo de decisões: sobre a estrutura orgânica, decisões políticas, econômicas, sociais, etc e se realiza uma vez por ano, por uma convocação do Diretório. Também podem ocorrer assembléias extraordinárias que são convocadas para tratar de temas específicos ou de emergência e as reuniões do Diretório que se realizam semanalmente (ESTATUTO ORGÂNICO DA CICOL, 2008).

Assim, também compreendemos que a assembleia funciona como a autoridade máxima de mando coletivo, onde há rotatividade e obrigatoriedade nas funções de autoridade, sendo aqui entendida como obrigação esse serviço, e não um privilégio como nos cargos e funções desempenhados pelos representantes do Executivo e Legislativo. Existe também uma prestação de contas e controle exercidos sobre esses representantes ou autoridades. Wood (2010) em seu livro, "Democracia contra o capitalismo" esclarece que a democracia representativa, com a universalização do voto, criou uma atuação individual e não mais de "corpo social" neste processo. A prática representativa deveria estar assentada na coletividade mas não está e a política veio despolitizar a sociedade. Nesse sentido, a democracia, na terra indígena de Lomerío, pode ser vista como comunitária porque a assembleia é um espaço privilegiado em que deliberam sobre assuntos da vida comunitária, constituindo-se como o principal objetivo em que expressam a vontade coletiva com a participação direta e colegiada dos dirigentes. Assim, a democracia aqui pode ser considerada ativa e direta, bem diferente dos moldes modernos. 
Luis Tapia também enfatiza o papel da assembleia nas democracias comunitárias. Para ele, a estrutura comunitária de assembleia é diferente do sistema de representação e parece ser uma forma de governo mais democrática tanto na primeira invenção grega quanto no governo de assembleia que são a base da representação. Porém, esta se organiza através da rotação dos cargos de autoridade; a diferença é que nas comunidades indígenas, o núcleo a partir do qual se define a presença na assembleia é a família e não as pessoas (TAPIA, 2009, p. 118).

$\mathrm{O}$ art. 10 do Estatuto Orgânico da CICOL também estabelece que:

Somos uma organização indígena com boa estrutura executiva e operacional com auto-gestão e baseada em regulamento próprio que incentiva a participação igualitária dos homens e mulheres ... (ESTATUTO ORGÂNICO DA CICOL, 2008). (tradução nossa).

A alcalde comunal (delegada) Maria de Lourdes Chuve, da comunidade de San Lourenzo, explicou que:

Nessa estrutura não existe uma área específica para as mulheres atuarem porque depois de uma análise sobre a pertinência ou não de se criar, as lideranças determinaram que o caráter da CICOL é o de representar toda a nação indígena chiquitana monkox de Lomerío. E dentro das estruturas criadas existe a possibilidade de participarmos ativamente e fortalecer essa estrutura ocupando esses espaços de representação e decisão tanto em assembleia quanto no diretório. Algumas mulheres das comunidades já estão entendendo a importância de ocupar esses espaços de decisão, mas ainda nossa participação é muito tímida nessas estrutura ${ }^{14}$ (CHUVE, 2015).

Nas comunidades visitadas (San Lourezo e El Puquio) pelo que pude observar, a estrutura organizacional apresenta aspectos muito parecidos com a da TCO para articularem e coordenarem as ações dessas comunidades e da TCO. Eles também têm uma assembleia a nível comunitário que é a autoridade máxima nessas comunidades. Eles elegem delegados, a nível comunitário, e desta eleição podem participar homens e mulheres, para uma vez eleitos (seis delegados por comunidade) poderem estar representando sua comunidade na assembleia geral da CICOL.

Antes da aprovação dessa nova estrutura organizacional da CICOL, em 2008, as autoridades comunais estavam dentro da estrutura organizativa da Organização Territorial de Base (OTB) com um presidente comunal, agora essas autoridades comunais denominam-se

\footnotetext{
${ }^{14}$ En esta estructura no existe una área especifica para las mujeres actuaren porque despúes de una analise en la pertinencia o no de se crear, los liderazgos determinaran que el caracter de la CICOL es lo de presentar toda la nación indigena chiquitana monkox de Lomerío. E dentro das estructuras creadas existe la posibilidad de participarmos activamente y fortalecer esa estructura tomando eses espacios de presentaciones y decisiones tanto en asamblea cuanto en el directório. Algunas mujeres de las comunidades ya están entendendo la importancia de ocupar eses espacios de decisión, pero todavia nuestra participación es muy tímida en esas estrutura
} 
delegados. Dessa assembleia, a nível comunitário, elegem o Conselho de Anciões, os delegados que são os executores das ações, e que podem inclusive compor o Diretório e serem um dos caciques. O diretório troca a gestão a cada quatro (4) anos.

É muito interessante perceber o quanto a CICOL significa para eles enquanto Organização Indígena e relembra suas conquistas. Segundo o 1 "gran cacique" da CICOL, o sr. Anacleto Peña em entrevista, em dezembro de 2015:

A CICOL mostra sua capacidade para reivindicar e consolidar os direitos do seu povo através de diversas ações articuladas às oportunidades que as mudanças normativas possibilitaram: a criação do sindicato (OTB), da participação nas marchas indígenas, a demanda e titulação territorial (19962006), a luta contra as empresas madeireiras que invadem nosso território para explorar nossos recursos, a obtenção do selo verde para o aproveitamento da madeira em nossa TCO, a experiência em educação intercultural bilíngue nas nossas escolas, a criação do município indígena monkox (1999), a declaração como primeiro território indígena autônomo (desde 2008), o treinamento de uma equipe técnica multidisciplinar local dentro da organização, a participação na Assembleia Constituinte, Nélida Faldín nos representou na assembleia em $2007^{15}$ (PEÑA, 2015).

É claro que a CICOL tem feito parcerias com ONG,s como a SNV - Netherlands Development Organisation dos Estados Unidos - que os ajuda nos projetos de exploração de madeiras e fabricação de produtos artesanais de forma sustentável, a CEJIS que auxilia juridicamente na condução do processo de consolidação da autonomia indígena junto ao Ministério de Autonomias e ao TCP, a APCOB que tem também os ajudado em projetos de aproveitamento ambientais. É perceptível que todo o apoio técnico jurídico ofertado a essas comunidades tem transferido conhecimentos técnicos, jurídicos e administrativos que fundamentam a atual co-gestão e que servem de suporte para assumirem a autogestão de seu território assim que o processo de autonomia estiver consolidado.

Adrian Marzec, atual conselheiro fiscal da APCOB, em entrevista em janeiro de 2015, explica sobre a atuação dessa ONG nas TCO,s de Monte Verde e Lomerío:

O projeto é uma parceria de cogestão, CICOL e APCOB, em que a CICOL administra os recursos econômicos destinados a investimentos produtivos, entradas, salários e jornada de trabalho e a APCOB somente auxilia com a assistência técnica qualificada. Cada programa é executado pela equipe da APCOB e a contrapartida é que a CICOL forneça o corpo técnico e de

\footnotetext{
${ }^{15}$ La CICOL mostra su capacidad para reivindicar y consolidar los derechos de su pueblo a través de diversas acciones articuladas a las oportunidades que los câmbios normativos posibilitaran : la creación del sindicato(OTB), de la participación en las marchas indigenas, la demanda y titulación territorial (1996-2006), la lucha contra las empresas de maderas que invaden nuestro território para explorar nuestros recursos, la obtención del sello verde para el aprovechamento de la madera en nuestra TCO, la experiência en educación intercultural bilingüe en las nuestras escuelas, la creación del município indigena autonóma (desde 2008), el entreinamento de uma equipo técnica multidisciplinar local dentro de la organización, a la participación en la Asemblea Constituinte, Nélida Faldín nos presenta en la asemblea en 2007.
} 
execução chiquitana, bem como os promotores dessas ações e dirigentes da $\mathrm{CICOL}^{16}$ (MARZEC, 2015).

Foi também a partir dessa parceria, cogestão, autogestão dos projetos, e executando o Plano de Gestão Territorial Indígena (PGTI) que a CICOL aponta como conquistas importantes todos os itens abaixo relacionados:

Quadro 5. Principais conquistas da CICOL

\begin{tabular}{|c|c|}
\hline $\mathrm{ANO}$ & AVANÇOS/CONQUISTAS \\
\hline 1982 & $\begin{array}{l}\text { Formação da organização e temas dessa } \\
\text { organização: território, produção, saúde e } \\
\text { educação; processo de filiação das } \\
\text { comunidades; relacionamento com as ONG,s; } \\
\text { início da elaboração dos regulamentos e } \\
\text { estatutos internos; }\end{array}$ \\
\hline $1982-2001$ & $\begin{array}{l}\text { Experiência em co-execução de projetos em } \\
\text { tema florestal com ONG,s até a autogestão; }\end{array}$ \\
\hline $1993-2003$ & $\begin{array}{l}\text { Luta contra as empresas madeireiras e } \\
\text { mineradoras em defesa do território; }\end{array}$ \\
\hline 1995-1996 & Demanda territorial para titulação da TCO; \\
\hline 1996-2006 & Processo de gestão para titulação do território; \\
\hline 1999 & $\begin{array}{l}\text { Criação do município indígena monkox } \\
\text { chiquitano San Antônio de Lomerío; }\end{array}$ \\
\hline $2001-2002$ & $\begin{array}{l}\text { Processo de construção metodológica e } \\
\text { elaboração do Plano de Gestão Territorial } \\
\text { Indígena (PGTI). }\end{array}$ \\
\hline $2002-2004$ & Elaboração dos planos comunitários; \\
\hline 2003 & $\begin{array}{l}\text { Início da execução dos projetos do Plano de } \\
\text { Gestão Territorial Indígena (PGTI); e criação } \\
\text { de gado para controle territorial; }\end{array}$ \\
\hline 2005 em diante & 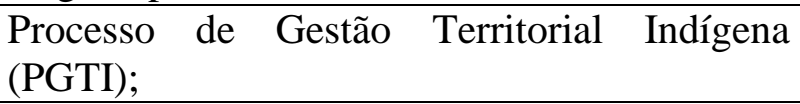 \\
\hline 2006 & $\begin{array}{l}\text { Instalação da Assembleia Constituinte; } \\
\text { titulação de } 259.118 \text { hectares a favor da TCO } \\
\text { Lomerío; }\end{array}$ \\
\hline 2007 & $\begin{array}{lcc}\text { Representante indígena monkox } & \text { na } \\
\text { Assembleia Constituinte - Nélida Faldín; } & \\
\end{array}$ \\
\hline 2008 & $\begin{array}{l}\text { Declaração como Primeiro Território Indígena } \\
\text { Autônomo; }\end{array}$ \\
\hline
\end{tabular}

Fonte: CICOL-GTI, 2008 (tradução nossa).

Peña, em entrevista, enfatiza que as diferentes etapas do processo de gestão territorial indígena (GTI), desde a elaboração dos diagnósticos, planejamento, regulamentos e

\footnotetext{
${ }^{16}$ El proyecto es una parceria de cogestión, CICOL y APCOB, en que la CICOL administra los recursos economicos destinados a la investimentos productivos, entradas, salarios y jornada de trabajo y la APCOB solamente auxilia con la asistencia técnica cualificada. Cada programa es ejecutado por la equipo de la APCOB es la contrapartida es que la CICOL proporciona el cuerpo técnico y de ejecución chiquitana, bem como los promotores de esas acciones y líderes de la CICOL.
} 
finalmente, a execução desses projetos se constituíram em oportunidades para que a organização indígena chegasse a todas as comunidades e, de maneira consensual definissem as visões conjuntas que guiam suas ações. Esse processo é desenvolvido por uma equipe técnica própria e é convalidado no Plano de Gestão Territorial Indígena (PGTI). Isso tem significado um ganho de experiências para o povo de Lomerío em execuções de projetos na prática (PEÑA, 2015).

Embora esse processo de gestão foi visto de forma positiva pois foi desempenhado pela equipe técnica local (GTI) e às ONG,s deram assessoria com apoio técnico ao Diretório, essa articulação acabou modificando às estruturas da organização política e impulsionou importantes mudanças na organização e na estrutura orgânica, principalmente nas denominações sindicais de então.

Peña esclarece que:

Apesar de todas essas ações recordo que desde a formação da organização até princípio dos anos 1990, a estrutura de organização tinha um bom funcionamento devido a unidade que o povo chiquitano mantinha e portanto, graças a sua cultura comum no processo de organização desenvolvido até ali. Porém, essa unidade começou a ser afetada com a partidarização das comunidades, momento em que representantes de partidos políticos tradicionais que vinham de Santa Cruz, pouco a pouco, causaram lutas internas como consequência da busca por votos tanto em eleições municipais quanto nacionais. Mesmo que a CICOL tenha deixado de pertencer ao município de Concepción e conseguiu criar o município indígena monkox chiquitano em 1999, sobre sua jurisdição territorial, os conflitos não terminaram, mas buscamos protagonistas locais ${ }^{17}$ (PENA, Anacleto, 2015).

Percebemos ainda na fala de Peña, que o relacionamento dos membros da CICOL com o governo municipal (San Antônio de Lomerío) está estremecido, e que as eleições municipais têm uma diferente maneira de participação (“caça aos votos para partidos”), e nem sempre elege representantes indígenas locais se comparado esse processo ao de representatividade coletiva que ocorre na CICOL.

Segundo um morador da comunidade de San Lourenzo, Manuel Pochochoa, entrevistado em janeiro de 2015, as assembleias, que representam as vinte e oito (28) comunidades através de seus delegados, devido a esse nível de participação e decisão compõe

\footnotetext{
${ }^{17}$ A pesar de todas esas acciones recuerdo que desde la formación de la organización (1982) hasta principio de los años 1990, la estrutura de organización tenía un buen funcionamento debido la unidad que el pueblo chiquitano mantenía y por lo tanto, gracias a la su cultura comun en el proceso de organización desarrollado hasta allí. Si embargo, esa unidad empiezo a ser afectada con la partidarización de las comunidades, momento en que líderes de partidos políticos tradicionales que venían de Santa Cruz, poco a poco, causaran luchas internas como consecuencia de la busca por votos tanto em elecciones municipales cuanto nacionales. Mismo que la CICOL tenga dejado de pertenencer al município de Concepción y logrou crear el município indigena monkox chiquitano en 1999, sobre su jurisdición territorial, los conflitos no terminarian , pero buscamos protagonistas locales.
} 
uma estrutura que tem legitimidade perante as comunidades por ser coletiva e comunitária. A pressão sobre o diretório é muito forte por envolver direta ou indiretamente todas as comunidades $^{18}$. Para ele, a CICOL é a única instância organizacional que sempre defendeu os direitos dos lomerianos liderando a execução de projetos e todos os avanços ocorridos em Lomerío se devem a CICOL.

Peña esclarece que essa relação tensa entre a CICOL e o governo municipal foi fruto em parte dos "jogos e conflitos" partidários que ocorrem em seu território desde 2004, pois ambos trabalham em prol do desenvolvimento das comunidades com uma única e grande diferença: a organização indígena há mais de 20 anos exerce a representação de seu povo e não conta com recursos econômicos do Estado ou do governo municipal, este tem uma estrutura política administrativa reconhecida pelo Estado e por lei mas deve a sua existência a própria CICOL. A falta de recursos econômicos para gerir a própria estrutura política organizacional da CICOL é tida como o maior dos problemas a ser enfrentado à nível de governança do território indígena ${ }^{19}$ (PEÑA, 2015).

A cacique de educação e cultura, moradora de El Puquio, Maria Cristina Surubí em entrevista em dezembro de 2015, salienta que a alcadía (prefeitura municipal) monopoliza muitas vezes o trabalho da organização e usurpa funções que não são de sua competência porque detém os recursos econômicos ${ }^{20}$ (SURUBÍ, Maria, Cristina, 2015).

Devido à luta pela consolidação da autonomia indígena, os alcaldes (prefeitura) que assumiram a gestão no município indígena de San Antonio de Lomerío desde 2008, não vêm tendo um nível de relacionamento com a CICOL muito cooperativo e romperam o apoio definitivamente desde 2013, quando o processo de consolidação de autonomia territorial foi enviado ao Tribunal Constitucional Plurinacional. Isso ocorreu porque vêem ameaçada a estrutura de governo municipal e ficam longe da CICOL demonstrando que existe uma

\footnotetext{
${ }^{18}$ las asamblea, que representan las veinte y ocho (28) comunidades a través de sus delegados, debido a ese nível de participación y decisión, es una estructura que tiene legitimidad ante las comunidades. La presión en el diectorio es muy fuerte por envolver directa o indirectamente todas las comunidades. La CICOL es la única instancia organizacional que siempre defendió los derechos de los lomerianos liderando la ejecução de proyectos y todos los avanzos ocurridos en Lomerío se deben la CCOL.

${ }_{19}$ Esa relación tensa entre la CICOL y el gobierno municipal, fue fruto en parte de los "juegos y conflitos" partidários que ocurren en su território desde 2004, pues ambos trabajan en prol del deserrallo de las comunidades con una única y gran diferencia: la organización indigena hay más de 20 años ejerce la representaciónde su pueblo y no cuenta con recursos economicos del Estado o del gobierno municipal, este tiene una estructura politica administrativa reconocida por el Estado y por ley pero debe la su existencia la própria CICOL. La falta d e recursos economicos para gerir la própria estructura politica organizacional de la CICOL es tomada como el mayor de los problemas a ser enfrentado a el nível de gobernancia del território indigena.

${ }^{20}$ La alcadía (gobierno municipal) monopoliza muchas veces el trabajo de la organización y usurpa funciones que no son de su competencia porque detiene los recursos económicos.
} 
posição de resistência da alcaldía em relação ao reconhecimento do governo territorial indígena.

A proposta de "ascender" à autonomia via estatal é defendida por muitos autores como possibilidade de revitalização de sua força representativa, ou mesmo como um potencial para melhorar a governabilidade democrática, uma vez que incluiria a diversidade multicultural em suas estruturas e reconheceria outras formas de organização. O poder político, no caso de Lomerío, já é exercido de forma legítima, democrática e participativa e portanto não estariam "ascendendo" mas consolidando, embora não seja reconhecido formalmente e legalmente pelo Estado nem receba recursos para isso.

No momento em que nos deparamos com a situação dos recursos econômicos estarem vinculados ao governo municipal e não existirem divisão desses recursos e repasses governamentais com a organização que viabiliza, na prática, direitos e o desenvolvimento das comunidades, sendo esta organização legitimada pelas comunidades, não percebemos o processo implementado pelo Estado como uma possibilidade de desarticulação da situação dominante de desigualdades. O município indígena não faz repasses nem articula-se com as referidas comunidades para melhorias das mesmas atuando apenas dentro do município.

\subsection{Reflexões sobre as tensões e enfrentamentos do processo jurídico-administrativo para consolidação da autonomia em Lomerío}

Esse item tem como objetivo evidenciar parte do processo jurídico-administrativo formal que a nação Monkóxi tem realizado para "ascender" à autonomia perante o Estado. Nesse sentido, trago como fontes de análise a descrição de alguns documentos que a CICOL e a CEJIS disponibilizaram, tais como, atas de reuniões e assembleias, cartas, resoluções e portarias ministeriais em que são apresentados os fundamentos jurídicos de cada ato, bem como depoimentos de algumas autoridades indígenas que acompanham esse processo evidenciando algumas tensões e estratégias estabelecidas para ver o Ministério das Autonomias reconhecer essa autonomia.

Os primeiros documentos enviados ao Ministério tiveram como objetivo obter o certificado de viabilidade de governabilidade, sendo apresentados em 12 de agosto de 2014 e, somente em 16 de dezembro de 2015 foi finalmente concedido. Muitos documentos foram exigidos e, portanto, o trabalho para cumprir as exigências e os requisitos começaram bem antes do próprio processo jurídico administrativo, entre os quais juntaram: certificação de condição de territorialidade ancestral que o Vice Ministério de Autonomias Indígenas 
Originárias Camponesa e de organização territorial expediu na forma de resolução administrativa em 26 de dezembro de 2013; estatuto orgânico da CICOL (2008); plano de gestão territorial (2009); dados populacionais e projeção de crescimento populacional (2012); título da TCO com mapa de localização com perímetros delimitados (1998); resoluções de Assembleias realizadas com as comunidades, que ocorreram em 2010 para ratificar a decisão do território indígena autônomo Monkóxi de Lomerío de consolidar a autonomia e dar mandato às autoridades e conselheiros para os representarem junto ao Ministério; e também, um documento que dava poderes especiais a Anacleto Peña, 1 gran cacique general da CICOL à época.

Muito interessante é o documento que também compôs essa primeira fase do processo, a Resolução n. 1 denominada: XXVI Grande Assembleia Geral Ordinária da Central Indígena de Comunidades Originárias de Lomerío (CICOL), cujo conteúdo era declarar a autonomia do povo indígena monkóx (chiquitano) de Lomerío, em 29/03/2008. Fundamentaram-se na Declaração de Direitos Indígenas das Nações Unidas, ratificada pela Lei n. 3760 de 7 de novembro de 2007, que estabeleceu que os povos indígenas teriam direito à livre determinação. Entenderam que o exercício desta, seria por meio da autonomia e autogoverno em que determinariam livremente sua condição política e o desenvolvimento econômico, social e cultural de seu território.

Outro documento importante foi a Convenção n. 169 da OIT, ratificado pela Lei n. 1257 de 11 de julho de 1991, estabelecendo que os povos indígenas gozavam de direitos humanos, liberdades fundamentais, sem obstáculos nem discriminação ao mesmo tempo em que, não poderia ser feito uso de força ou coerção que violasse os seus direitos. Ainda, nessa mesma lei, garantiram o direito de serem consultados mediante procedimentos apropriados através de instituições representativas cada vez que realizassem medidas legislativas ou administrativas suscetíveis de os afetarem diretamente.

A lei n. 2650 de 13 de abril de 2004 também foi utilizada nessa fundamentação pois esta, reconheceu e estabeleceu respeito e proteção aos direitos sociais, econômicos e culturais dos povos indígenas que habitassem o território nacional, com especial ênfase nos direitos relativos às terras comunitárias de origem (TCO,s), garantindo o uso e o aproveitamento sustentável dos recursos naturais e o exercício das suas identidades, valores, línguas, costumes e instituições. O documento foi assinado por representantes da CICOL, autoridades das comunidades, da CIDOB e OICH (DECLARAÇÃO DE AUTONOMIA DO POVO CHIQUITANO MONKÓX, 2008). (tradução nossa).

Em entrevista Peña esclarece: 
Declararmo-nos o primeiro território autônomo indígena da Bolívia foi uma ação política assim como a construção da gestão territorial indígena que foi o nosso instrumento de exercício de autonomia. Nosso povo chiquitano foi quem iniciou a luta pela liberação da escravidão de nossos irmãos que são submetidos aos patrões, ao saque do seu território por madeireiros e mineradores. Desde o fim da década de 1970, participamos da fundação do movimento indígena de terras baixas, organizando-nos para a defesa, a luta e a reivindicação dos nossos legítimos direitos que sempre tivemos como horizonte: a autonomia indígena. A outra estratégia foi deixar claro nesse documento que iríamos redigir nosso estatuto de autonomia indígena originária camponesa de acordo com nossas normas e procedimentos ${ }^{21}$ (PEÑA, 2015).

É evidente que consideram esse processo muito importante e essa consolidação é uma aspiração histórica com uma constante busca não só para ocuparem os espaços que ancestralmente os pertencem mas também, para construírem o próprio desenvolvimento considerando a sua identidade cultural, formas de viver e de se organizar.

Em 14 de abril de 2009, o Presidente da República (da etnia uru-aimará) sancionou a Lei do Regime Eleitoral Transitório n. 4021, que previa a possibilidade de conversão dos municípios em autonomias territoriais indígenas (AIOC,s). A partir de então, funcionários do Ministério das Autonomias têm transmitido essa proposta aos dirigentes nacionais, departamentais e também ao povo chiquitano para que a Central Indígena adote esse tipo de autonomia para "ascenderem" convertendo o município de San Antonio de Lomerío em uma AIOC, de acordo com o que estabelece o artigo 294, inc. II da Constituição (DOCUMENTO DO MINISTÉRIO DE AUTONOMIAS, 2009). (tradução nossa).

Em resposta a esse documento, a Central Indígena de Comunidades Originárias de Lomerío (CICOL) se posicionou contrária a essa proposta e enviou uma carta ao Ministro de Autonomias Carlos Romero, em 26/05/2009, contendo os seguintes argumentos:

Em primeiro lugar, o município de San Antonio de Lomerío foi criado pela lei n. 3031 de 18/03/1999, sob a base jurisdicional da região de Santa Rosa del Palmar em que, até então, era parte do município de Concepción. A figura republicana do município foi reconhecida como uma conquista do longo caminho da consolidação do território e da demanda de autogoverno como povo indígena. Por outro lado, o processo de saneamento e titulação da TCO de Lomerío possibilitou a recuperação de espaços ancestrais que foram bem além da jurisdição deste município e agora detemos a propriedade

\footnotetext{
${ }^{21}$ Nos declararmo el primero território autônomo indigena de la Bolívia fue una acción politica asi como la construción de la gestión territorial indigena que fue el nuestro instrumento de ejercicio de autonomia. Nuestro pueblo chiquitano fue quién inicio la lucha por la liberación de la esclavitud de nuestros hermanos que son submetidos a los patrones, al saque de su território por maderero y mineradores. Desde el fin de la década de 1970, participamos de la fundación del movimento indigena de tierras bajas, nos organizando para la defesa, la lucha y la reividicación de nuestros legítimos derechos que siempre tuvimos como horizonte: la autonomía. La outra estratégia fue dejar claro en ese documento que iriamos escribir nuestro estatuto de autonomía indigena originária campesina de acuerdo con neuestras reglas y procedimentos.
} 
territorial de uma superfície de 259.188,72 hectares, incluindo ai a área municipal. Em segundo lugar, em 29/03/2008, a Assembleia Ordinária da CICOL declarou a TCO Lomerío como o primeiro território indígena autônomo de Monkóxi de Lomerío com base em documentos internacionais e leis nacionais. A decisão que tomamos foi a de consolidar a autonomia indígena com base em nosso território titulado como TCO, e a mesma foi comunicada ao presidente do Congresso e ao presidente da República, sendo ratificada em Assembleia Ordinária da CICOL na data de 28/03/2009. Em terceiro lugar, acreditamos que o artigo 293 da nova Constituição Política do Estado reconhece o caso de Lomerío, pois estabelece no parágrafo primeiro, que a autonomia indígena está baseada em territórios indígenas consolidados, ou seja, que se constituíram por vontade expressa da população em consulta, de acordo com suas normas e procedimentos. Por sua vez, a disposição transitória VII estabeleceu que a base de delimitação dessa autonomia indígena é a terra comunitária de origem como a que temos garantido por titulação (CARTA DA CICOL AO MINISTÉRIO DAS AUTONOMIAS, 2009) $)^{22}$. (tradução nossa).

Assim, entenderam que o artigo 293, inciso I da CPE, reconhece plenamente suas expectativas e se ajusta melhor à realidade de Lomerío permitindo que nesse processo, pela via territorial, os conduza ao exercício da livre determinação estabelecido na nova Constituição, nas convenções e declarações internacionais que reconhecem esse direito. A via municipal, disposta no artigo 294, II da CPE e agora regulamentado pela Lei do Regime Eleitoral Transitório n. 4021 também é uma proposta válida mas não se encaixa na situação territorial, política, institucional e cultural que vivenciam nesse território.

Peña esclareceu também que:

Me parece que se aceitássemos a proposta do Estado estaríamos renunciando ao exercício de democracia comunitária e da aplicação de nossas normas próprias. E este foi o único requisito exigido para ascendermos à autonomia que realmente concordamos. A TCO tem sua estrutura e normas próprias, então, estaríamos nos submetendo à democracia liberal ou seja, a sua forma

\footnotetext{
${ }^{22}$ Carta de la CICOL: En primero lugat, el município de San Antonio de Lomerío fue creado por la ley n.3031 de 18/03/1999, sob la base jurisdicional de la región de Santa Rosa del Palmar en que, hasta entonces, era parte del município de Concepción. La figura republicana del município fue reconocida como una conquista de un largo camino de la consolidación del território y de la demanda de autogobierno como pueblo indígena. Por outro lado, el proceso de saneamento y titulación de la TCO de Lomerío possibilito la recuperación de espacio ancestrais que fueran bien más alla del jurisdición de este município y ahora detenermos la propiedad territorial de una superficiede 259.188,72 hectares, incluindo ahí la área municipal. En según lugar, en 29/03/2008, la Asamblea Ordinaria da CICOL declaro la TCO Lomerío como el primer território indigena autonomo de Monkoxi de Lomerío con base en documentos internacionales y leyes nacionales. La decisión que tomamos fue a de consolidar la autonomía indigena con base en nuestro território titulado como TCO, y la misma fue comunicada al presidente del Congreso y al presidente de la República, sendo ratificada en Asamblea Ordinaria da CICOL em la data de 28/03/2009. En terceiro lugar, creemos que el artículo 293 de la nueva Constituición Politica del Estado reconoce el caso de Lomerío, pues estabelece em el párrafoprimero, que la autonomía indígena está basada em territórios indigenas consolidados, ou sea, que se constituíran por voluntad expresa de la populación en consulta, de acuerdo con sus reglas y procedimentos. Por su vez, la disposición transitória VII estableció que la base de delimitación de esa autonomía indigena es la tierra comunitária de la origen como la que tenenmos garantido por titulación.
} 
de governo com referéndun e decisões do governo municipal ${ }^{23}$ (PEÑA, 2015).

Isso resultaria em deixar de lado toda a base territorial que representa a TCO para estruturar um futuro governo, que no caso de Lomerío, abrange uma área de jurisdição maior que a do município de San Antônio deixando de fora a atual cobertura administrativa e institucional das comunidades e seus recursos, que estão fora do município porém, dentro de seu território.

A parte final do documento, além de reforçar que não aceitavam a conversão do município de San Antônio de Lomerío em autonomia indígena originária camponesa (AIOC), conforme estabelecia o art. 294, II da CPE, por não se enquadrar na realidade vivenciada por Lomerío, também solicitavam que se construísse de forma participativa uma regulamentação para o artigo 293, I da CPE, a fim de que essa norma permitisse o exercício pleno dos direitos indígenas para a construção dessa autonomia (CARTA DA CICOL AO MINISTÉRIO DAS AUTONOMIAS, 2009).

No encontro sobre autonomia territorial, realizado em 14/07/2009, que contou com a participação de 21 das 28 comunidades de Lomerío, debateram e analisaram o processo de autonomia deste território. A CICOL elaborou a resolução n. 5, conforme Ata da resolução n. 5 de 2009, onde enfatizaram a vontade de Lomerío em transformar-se em uma entidade territorial autônoma, como o primeiro território indígena autônomo da Bolívia, bem como deu posse a um Conselho da Autonomia Indígena de Lomerío para redigirem e conduzirem a aprovação do Estatuto de Autonomia Indígena Originário Campesino, de acordo com suas normas e procedimentos.

Em 2010 iniciaram o processo de adequação do Estatuto de Autonomia nas oficinas comunais, zonais e assembleias gerais da CICOL listando datas em que estiveram em todas as comunidades para informarem e promoverem ajustes ao Estatuto, conforme procedimentos estabelecidos pela Lei Marco de Autonomias e Descentralização (LMAD,2010) e em 18 de outubro de 2012, reuniram-se em uma sessão de mesa técnica para concluir o trabalho de revisão e adequação do Estatuto a nova CPE e a LMAD vigentes. A ata 001/2013, elaborada na XXX Assembleia Ordinária da CICOL em 6/04/2013, apresentou os avanços realizados no Estatuto aos representantes das comunidades da assembleia aprovando este estatuto depois da

\footnotetext{
${ }^{23} \mathrm{Me}$ parece que se aceptamos la proposta del Estado estaríamos renunciandoal ejercicio de democracia comunitária y de la aplicación de nuestras reglas próprias. Y este fue el único requisito necesario para aascendermos la autonomía que realmente concordamos . La TCO tiene su estructura y reglas próprias, entonces, estaríamos nos sometendo a la democracia liberal o sea, a su forma de gobierno con referendu y decisiones del gobierno municipal.
} 
adequação a CPE e a LMAD e encaminhando o mesmo ao Tribunal Constitucional Plurinacional para consolidarem a autonomia de base territorial em Lomerío.

$\mathrm{Na}$ carta denominada de Breve referência do processo de autonomia indígena de base territorial da nação Monkóxi de Lomerío da CICOL de 24/04/2014, enviada ao Ministério das Autonomias, enfatizam que os catorze (14) requisitos criados pelo Estado para "ascenderem" à autonomia se tornam um grande obstáculo para verem avançar essa autonomia de base territorial, mas seguirão apostando ser possível o sonho de consolidarem à autonomia desse território que demorou onze (11) anos para ser reconhecido e titulado pelo Estado Plurinacional. Salientam também que, não aceitam a autonomia via municipal, e que, independentemente do reconhecimento legal pelo Estado, essa autonomia tem sido exercida no território indígena. Finalizam reiterando todos os dispositivos legais e legislação que se baseiam para requererem a autonomia.

Em 25/04/2014, o diretório da Assembleia Geral da CICOL convocou a "Assembleia Autonômica" para apresentarem a documentação solicitada aos membros do Serviço Intercultural de Fortalecimento Democrático (SIFDE). Segundo Maria Choré Oliz, 1 cacique do Conselho de Autonomia Indígena, "esse órgão tem a finalidade de supervisionar as atividades desenvolvidas, incluindo a análise do Plano de Desenvolvimento Integral (PDI) a nível de todas as comunidades para poderem avançar no acesso a autonomia". Nessa assembleia foi realizada a planificação desse PDI, entrega de documentação a esse órgão auxiliar ao Ministério das Autonomias e socialização dos avanços feitos em relação ao processo de autonomia de base territorial (ATA DA ASSEMBLEIA AUTONÔMICA DA NAÇÃO MONKÓXI, 2014). Ainda segundo ela:

O Conselho de Autonomia Indígena produz também uma pressão a esse Ministério e em todas as oportunidades formais também exigimos orientações e explicações sobre as etapas que seguimos alcançando. Porém, sabemos que outros passos são importantes como articular uma maior quantidade de relações interinstitucionais tanto em nível público quanto privado. Sabemos também que é muito importante socializarmos os resultados desse processo autonômico, quanto mais evidência mais força ganhamos e é isso que também fazemos nessas assembleias com representantes do governo fazendo-os nos dar respostas e alternativas aos problemas encontrados. Ainda, devemos avançar mais, no sentido de exigir apoio dos nossos representantes do órgão legislativo plurinacional com os deputados e senadores para que nos ajudem a concretizar tal objetivo ${ }^{24}$ (OLIZ, 2015).

\footnotetext{
${ }^{24}$ El consejo de Autonomía Indigena produz también una presión a ese Ministerio y en todas las oportunidades formales también exigimos orientaciones y explicaciones em las etapas que seguimos alcanzando. Sin embargo, sabemos que otros pasos son importantes como articular una mayor cuantidad de relaciones interinstitucionales tanto en nível publico cuanto privado. Sabemos también que es muy importante socializarmos los resultados de este proceso autônomo, cuanto más evidencia más fuerza ganamos y es eso que también hacemos en esa
} 
Maria Choré Oliz, primeira cacique do Conselho de Autonomia Indígena, e Anacleto Peña, cacique geral da CICOL, redigiram uma sustentação juntamente com a solicitação de controle de constitucionalidade do projeto de Estatuto de Autonomia ao Tribunal Constitucional Plurinacional (TCP) em 17/12/2012. Fundamentam sua solicitação abordando os seguintes aspectos: 1) o passado histórico do povo chiquitano; 2) reconhecimento e titulação da TCO Lomerío da nação Monkóxi que iniciou em 1971 e só foi concluído em 1998; 3) a CICOL enquanto representante legítima da Assembleia da Autonomia Indígena; 4) a construção de autonomia indígena de base territorial fundando-se não apenas no marco legal mas também histórico desse processo; 5) o processo de elaboração e aprovação do estatuto a nível de TCO; 6) suporte legal para a autonomia; 7) conteúdo do projeto em concordância com a Constituição e cumprindo os conteúdos mínimos do art. 62 da lei Marco de Autonomias e Descentralização (SOLICITAÇÃO DE CONTROLE DE CONSTITUCIONALIDADE DO ESTATUTO DE AUTONOMIA, 2014).

A Lei Marco de Autonomias e Descentralização de 2010, em seu artigo 62, traz os conteúdos mínimos que os Estatutos e Cartas Orgânicas devem conter, e fiz uma remissão a essas adaptações para atendimento dos critérios que constam no Estatuto, a seguir detalhados: 1. Declaração de sujeição à Constituição Política do Estado e as leis do Estado: o que foi atendido no artigo 4 do Estatuto;

2. Identidade da entidade autônoma: expressa no art. 8 do Estatuto com a denominação dessa nação indígena;

3. Localização de sua jurisdição territorial: contido no artigo 3 sobre jurisdição territorial;

4. Estrutura organizacional e identificação das autoridades: detalhamento no artigo 24 sobre a assembleia geral, artigo 30 sobre o órgão executivo, artigo 35 sobre o órgão legislativo e artigo. 40 sobre a administração da justiça no território;

5. Forma de organização do órgão legislativo ou deliberativo: expresso no artigo 35;

6. Faculdades e atribuições das autoridades assegurando o cumprimento das funções executiva, legislativa e deliberativa, organização, funcionamento, procedimento de eleição, requisitos, período de mandato: artigos 24 aborda a assembleia geral, artigo 25 sobre a composição da assembleia e formas de eleição, artigo 25 sobre a convocação das eleições, o artigo 25 sobre as atribuições das assembleias, artigo 30 aborda o órgão executivo, o 31 sobre as formas de eleição, o 32 estabelece os requisitos e período das funções, artigo 33 são as

asamblea con representantes del gobierno haciendo nos dar repuestas y alternancias a los problemas encontrados. Todavía, debemos avanzar más, em el sentido de exigir apoio de los nuestros representantes del órganos legislativo plurinacional con los deputados y senadores para que nos ayuden a concretizar tal objetivo. 
atribuições, artigo 35 sobre o órgão legislativo, o 36 sobre o período das funções, o 37 sobre as formas de eleição, o 38 sobre as atribuições, o 39 sobre os requisitos, o artigo 40 sobre a administração da justiça, o 41 sobre as autoridades das comunidades que administram a justiça, o 42 sobre o Conselho de Anciãos, o 43 sobre a composição, forma de eleição e duração do mandato, o artigo 44 sobre os requisitos e o artigo 45 sobre as atribuições.

7. Disposições gerais sobre a planificação, administração de seu território e regime financeiro, assim como estabelecer claramente as instituições e autoridades responsáveis pela administração e controle dos recursos fiscais: artigo 58 aborda os critérios, o 59 sobre as fontes de financiamento e o 60 sobre os recursos da entidade territorial autônoma.

8. Previsões para descentralizar-se administrativamente em caso de necessidade: artigo 34 estabelece as unidades técnico-operativas;

9. Mecanismos e formas de participação e controle social: artigo 51 sobre a participação e controle social;

10. O regime para minorias ou seja, pertencentes a nações e povos indígenas que não são desta nação e que habitem a jurisdição: artigo 69 parágrafo III que aborda sobre os terceiros;

11. Regime de igualdade de gênero e de pessoas com deficiências: artigo 17 sobre igualdade de gênero, 18 sobre crianças e adolescentes, 19 sobre a juventude, 20 sobre o adulto maior, e o 21 sobre as pessoas com deficiências;

12. relações institucionais da entidade autônoma: artigo 56 aborda as competências compartilhadas;

13. Procedimentos da reforma do estatuto, total ou parcialmente: disposições finais;

14. Disposições que regulem a transição até a aplicação total do estatuto ou Carta orgânica em correspondência com o estabelecido em lei: disposições finais.

O Tribunal Constitucional Plurinacional (TCP), em 31/03/2014, produziu um documento denominado Auto Constitucional 0111/2014, que teve como objetivo se pronunciar no trâmite processual verificando o cumprimento dos requisitos formais para admitir o projeto de Estatuto e posteriormente, passarem ao efetivo controle de constitucionalidade. No item "análise do cumprimento de requisitos de admissão", a juíza presidenta Dra Neldy Virgínia Andrade Martinez relatou o que esta Comissão de Admissão entendeu: que o solicitante não cumpriu o requisito que exigia a manifestação de parte de sua população, com prévia consulta, para a declaração de autonomia conforme prevê o artigo 293, inciso I da Constituição. Como não cumpriram esse requisito não foi possível admitir o projeto para o controle de constitucionalidade devendo o mesmo, primeiramente ser 
cumprido, para voltarem a examinar o projeto de estatuto e ser realizado o controle de constitucionalidade (AUTO CONSTITUCIONAL DO TRIBUNAL CONSTITUCIONAL PLURINACIONAL 0111/2014) (tradução nossa).

Ou seja, a juíza entendeu que não houve prévia consulta e manifestação de vontade dessas comunidades para fazerem parte da nação autônoma e desconsiderou todo o processo e luta pela autonomia bem como, a forma que foi feita essa consulta.

Em resposta a essa manifestação do TCP, Anacleto Peña produziu a impugnação desse ato constitucional esclarecendo que: tanto o memorial da solicitação quanto os itens subsequentes explicam com detalhe o processo em que, a população das 28 comunidades que integram a nação Monkóxi, definiram o exercício de sua livre determinação e declararam-se o primeiro território autônomo a nível nacional. Essa definição foi ratificada pelas instâncias orgânicas da CICOL, em assembleias com todas as comunidades, consolidando-se também com a comissão político-técnico da CICOL, com a participação do diretório da CICOL e representantes das 28 comunidades (IMPUGNAÇÃO AO AUTO CONSTITUCIONAL 0111/2014) (tradução nossa).

Soqueré, dirigente das comunidades originárias de Lomerío, esclareceu também:

Não apenas a declaração de autonomia tem a participação das comunidades como também a elaboração e aprovação do próprio estatuto que, após às adequações a LMAD coordenadas pela CICOL e pelo Conselho de Caciques da Assembleia, começaram a realizar vários eventos nas zonas do território com a participação das 28 comunidades para adequar a proposta de estatuto ao que foi estabelecido na lei. Foi um processo altamente participativo e teve a duração de mais de 3 anos. Concluído foi aprovado pelos membros do órgão deliberativo e é por isso que foi enviado ao tribunal para o controle de constitucionalidade ${ }^{25}$ (SOQUERÉ, 2016).

Soqueré ainda argumenta que os funcionários das prefeituras e os dirigentes cívicos devem reconhecer este estatuto indígena e respeitar os direitos dos povos originários, não devendo predominar apenas a autonomia departamental. Isso também significa respeito à Constituição Política do Estado e ao processo de legalidade. E finaliza: "Queremos que a população saiba que não existe apenas o estatuto departamental que vem se impondo pela

\footnotetext{
25 No solamente la declaración de autonomia tiene la participación de las comunidades como también la elaboración y aprovación del proprio estatuto que, después de las adaptaciones la LMAD coordenadas por la CICOL y por El Consejo da Asamblea, empieza a realizar diversos eventos nas áreas del território con la participación de las 28 comunidades para adecuar la proposta de estatuto al que fue establecido en la ley. Fue un proceso altamente participativo y tuve la duración de más de 3 anos. Concluido fue aprobado por los miembros del órganos deliberativo y es por eso que fue enviado al tribunal para el controle de constitucionalidad. Queremos que la populación sabe que no existe solamente el estatuto departamental que viene se imponiendo por la fuerza, pero también existe un outro estatuto, legitimo y realizado de forma consensual.
} 
força, mas também existe um outro estatuto, legítimo e realizado de forma consensual" (SOQUERÉ, 2016).

\section{Conclusão}

Pensamos que esse Estado forja a cada etapa as adaptações sem considerar as especificidades de cada nação indígena. Essa nova roupagem molda o processo de autonomia e os inclui apenas no aspecto formal, mas na prática, continua sendo um processo extremamente excludente, pois, os assujeitam. Ou seja, o Estado ainda não se efetivou plurinacional, apenas reconheceu a diversidade. E o direito, continua sendo um direito, na Bolívia, que condiciona os critérios para ascensão às autonomias, que produz as condições para aprovação e ajustes dos seus estatutos, que precisa do reconhecimento do Estado para serem considerados originários, que se esforça em modificar as formas de vida e organização e que caminha para um conceito único e geral de desenvolvimento, que cria uma nova estrutura de Tribunal para aprovação dos estatutos e para decidir em grau de recursos os conflitos que ocorreram nas comunidades e que condiciona os repasses tributários a essas adequações estruturais de suas organizações sociais para então conquistarem o autogobierno.

A compreensão dos aspectos culturais, sociais, políticos e administrativos que nos levaram até as categorias descolonização e autonomia, enquanto um movimento autônomo dos grupos indígenas de consolidação de autonomia e do protagonismo indígena, abordado a partir da impressão desse grupo sobre o processo nos assinala que a pesquisa de campo, vem colocando em evidência uma, das várias etapas dessa trajetória de lutas. Essa etapa vem demonstrando que são possíveis as mesclas, as adaptações, as mudanças, as combinações e que até o momento não foi possível solapar esses sujeitos e protagonistas da sua história que estão apreendendo, absorvendo, ajustando-se e também demonstrando sua capacidade de retornar, de lutar, de produzir recuos, de resistir, mas até quando? E de que formas? Quando vejo no olhar das lideranças, como Peña, uma força para assumir seu protagonismo vejo ainda resistências sendo elaboradas: "mesmo que demore 100 anos, mesmo que nos neguem, seguiremos e não desistiremos de alcançar o sonho de sermos autônomos e exercer nossa autodeterminação"26 (PEÑA, 2015). Nesse contexto, ainda estão escrevendo esse processo de luta por autonomia dentro do que consideram o Estado Plurinacional.

\footnotetext{
26 “Mismo que retraso 100 años, mismo que nos niegan, seguiremos y no desistiremos de alcanzar el sueño de sermos autonómos y ejercer nuestra autodeterminación”.
} 


\section{Referências Bibliográficas}

ARAOZ, M. Amparo; FERNÁNDEZ, Maroco A. Patiño (2010). El ejercicio em las TCO,s Lomerío, MOsetén y Chacobo-Pacahuara. Santa Cruz: Fundación PIEB.

GONZÁLEZ, Miguel (2008). Governing multi - ethnic societies in Latin America:

Regional autonomy, Democracy, and the State in Nicaragua: - 1987-2007. Tesis de Doctorado. York University: Toronto.

PUHL, João Ivo (2011). Territorialidades chiquitanas em comunidades rurais da Província de Velasco - Bolívia - 1953-2006. São Leopoldo-RS: UNISINOS.

TAPIA, Luis (2009). Lo político y lo democrático em los movimentos sociales. Em: TAPIA, Luis (coord). Democracia y teoria política em movimento. La Paz: CIDES UMSA- IDR ( p. 109-122).

WOOD, Ellen Meiksins. Democracia contra o capitalismo: a renovação do materialismo histórico. São Paulo: Boitempo, 2010.

\subsection{Entrevistas}

ADRIÉN MARZEC. Conselheiro Fiscal da APCOB. Entrevistado por Vívian Lara Cáceres Dan no escritório da APCOB em 22/01/2015. Concepción - Bolívia.

MIGUEL VARGAS. Abogado da CEJIS. Entrevistado por Vívian Lara Cáceres Dan em 22/04/2015 de 2015 na sede da CEJIS. Santa Cruz de La Sierra - Bolívia.

ANACLETO PEÑA. 1 gran cacique da CICOL. Entrevistado por Vívian Lara Cáceres Dan na sede da CICOL em 09/12/ 2015. El Puquio - Bolívia.

JUSTO SEOANE. 1 gran cacique general da OICH. Entrevistado por Vívian Lara Cáceres Dan em 24/01/2015 na sede da OICH. Concepción - Bolívia. 
IGNACIO GARCÍA. Ex liderança comunitária, membro do Conselho dos Anciãos de El Puquio da TCO de Lomerío. Entrevistado por Vívian Lara Cáceres Dan em 21/01/2016. El Puquio - Bolívia.

MARIA DE LOURDES YOPIE CHUVE. Autoridade Comunale. Entrevistada por Vívian Lara Cáceres Dan em 13/12/2015. Limoncito - Bolívia.

MARIA CRISTINA SURUBÍ. Cacique de educação e cultura. Entrevistada por Vívian Lara Cáceres Dan em 10/12/2015. El Puquio - Bolívia.

MARIA CHORÉ OLIZ . 1 cacique do Conselho de Autonomia Indígena. Entrevistada por Vívian Lara Cáceres em 10/12/2015. Palmira - Bolívia. 